\title{
PEMBENTUKAN WAWASAN GLOBAL MAHASISWA DALAM MATA KULIAH PENDIDIKAN KEWARGANEGARAAN DI FKIP UNIVERSITAS AHMAD DAHLAN
}

\author{
Syifa Siti Aulia \\ Prodi PPKn FKIP Universitas Ahmad Dahlan \\ email: syifasitiaulia@ppkn.uad.ac.id
}

\begin{abstract}
This research was aimed at answering about globalizing challenges citizen, especially young citizen. Teaching and learning in higher education including Citizenship Education is still conventional emphasizing learning process as the process of inculcating the value of smart and good citizen mainly related to the establishment of global competence of citizens. This study uses qualitative approach to explore the meaninful of practices and sciences of Citizenship Education as character education and global competencies of citizens. Practically, this research was expected to provide for practitioners and scientists of education, especially for Citizenship Education as character development courses in college, especially in the formation of global competencies of young citizens.
\end{abstract}

Keywords: global competencies, young citizens

\section{PENDAHULUAN}

Pendidikan Kewarganegaraan sebagai sarana efektif dalam proses pembentukan warga negara yang baik yang secara sederhana dapat dijelaskan bahwa warga negara yang baik adalah warga negara yang mengenal hak dan kewajibannya dalam kehidupan berbangsa, bernegara, sampai pada kehidupan berhubungan dengan bangsa lain. Takaran warga negara yang baik dapat dibentuk melalui Pendidikan Kewarganegaraan yang secara proses pelaksanaannya dapat dikaji dalam proses pendidikan di persekolahan, perguruan tinggi, dan pendidikan non formal.

Pelaksanaan pendidikan dalam prosesnya tidak dapat terlepas dari arus globalisasi yang masuk begitu cepat dalam kehidupan warga negara, sehingga diperlukan proses Pendidikan Kewarganegaraan yang siap menghantarkan tujuannya membentuk warga negara yang baik yang siap menghadapi masuknya arus globalisasi.

Globalisasi merupakan proses yang terus bergerak memasuki ranah-ranah yang tak pernah terbayangkan sebelumnya sehingga mobilisasi begitu cepat dan masif. Konsekuensinya adalah warga negara muda tidak bisa mengisolasi diri dari globalisasi dan harus memiliki wawasan global. Dengan demikian pembentukan warga negara berwawasan global (global citizen) mutlak diperlukan. Noddings ( 
(Rapoport, 2008, p. 92) mengatakan bahwa "a global citizen is one who can live and work effectively anywhere in the world, supported by a global way of life". Dari paparan di atas penekanannya ada pada eksistensi warga negara dalam konteks kehidupan global.

Menanggapi tantangan global di atas, maka dalam proses implementasinya Pendidikan Kewarganegaraan di salah satu lingkungan pendidikan yakni di perguruan tinggi hendaknya berorientasi pada pembentukan wawasan global untuk warga negara sebagai proses pembentukan warga negara yang baik seperti yang diharapkan Noddings di atas. Cheng mengatakan bahwa kurikulum dan pembelajaran yang perlu dikembangkan untuk abad ke 21 ini seyogianya mengembangkan visi "globalization, localization, and individualization for multiple intelligence" (Winataputra \& Budimansyah, 2007).

Pendidikan Kewarganegaraan yang dikembangkan di perguruan tinggi sebagai bagian pengembangan dimensi program kulikuler kewarganegaraan hakikatnya memiliki tujuan sama secara umum dalam pembentukan warga negara muda yang baik. Mahasiswa sebagai bagian dari warga negara muda dihadapkan pada era globalisasi dengan efek pertumbuhan teknologi informatika dan perkembangan ekonomi dunia. Tantangan tersebut hendaknya dapat dijawab melalui pembelajaran Pendidikan Kewarganegaraan. Pembelajaran Pendidikan Kewarganegaraan di konteks perguruan tinggi dalam era globalisasi hendaknya dapat membentuk warga negara yang memiliki kemampuan untuk memasuki abad baru dengan mahasiswa sebagai young citizen yang mampu menanggapi dan memfokuskan diri pada elemen-elemen yang beragam termasuk di dalamnya berbagai elemen dalam konteks global, namun tetap memegang teguh jati diri bangsa dengan selalu berusaha untuk meningkatkan kecintaan terhadap tanah air dalam menunjukkan good character yang dapat mengangkat harkat dan martabat bangsa.

Mahasiswa memiliki kecenderungan untuk sulit berinteraksi berdasarkan nilai-nilai dalam kehidupan masyarakat yang seharusnya terfasilitasi oleh proses pembelajaran sehingga memberikan dampak sikap-sikap mahasiswa yang menjauh dari karakter baik sebagai bagian dalam perkembangan kepribadian mahasiswa dalam lingkup pendidikan karakter. 
Berdasarkan latar belakang di atas, dapat diidentifikasi beberapa asumsi penelitian sebagai berikut:

1. Arus globalisasi dihadapkan pada seluruh komponen warga negara termasuk young citizen. Tantangan arus globalisasi membuat pergeseran nilai -nilai kehidupan yang baik (good character) di kehidupan young citizen.

2. Pembelajaran di lingkungan pendidikan tinggi termasuk Pendidikan Kewarganegaraan dijadikan sebagai proses pembentukan smart and good citizen terutama berkaitan dengan pembentukan kompetensi wawasan global warga negara.

3. Wawasan global warga negara merupakan tujuan dari pendidikan kewarganegaraan dalam paradigma baru terutama berkaitan dengan kompetensi kewarganegaraan sebagaimana yang dikemukakan oleh Branson (1998:16) yakni "civic knowledge, civic skill, dan civic disposition".

4. Kompetensi wawasan global warga negara merupakan karakteristik warga negara dalam mengatasi segala tantangan yang akan dihadapi dalam percaturan dunia global atau internasional sebagaimana yang dikemukakan oleh Cogan and Derricott dalam Budimansyah, Dasim dan Karim Suryadi (2008:39) yang menjelaskan "karakteristik sebagai warga negara yang sukses selama fase pertama abad ke-21 sebagai bentuk kompetensi-kompetensi warga negara global".

\section{METODE PENELITIAN}

Jika seorang peneliti memilih suatu metode penelitian maka akan membantu keberhasilan suatu penelitian karena hal ini akan memperjelas langkah-langkah maupun arah dari penelitian itu. Mertens (2010, p. 225) menyatakan bahwa "qualitative researchers study things in their natural settings, attempting to make sense of, or to interpret, phenomena in terms of the meanings people bring to them". Oleh karena itu karena salah satunya dipersyaratkan adanya setting penelitian yang natural maka cocok dengan penelitian ini yang ingin mengungkapkan proses, aktifitas dan hambatan mahasiswa dalam pembelajaran Pendidikan Kewargangeraan untuk membentuk perspektif global mahasiswa di Fakultas Keguruan dan Ilmu Pendidikan Universitas Ahmad Dahlan 
Selanjutnya yang menjadi pertimbangan pemilihan jenis penelitian ini juga dikemukakan Moleong (2010, p. 6) mensintesiskan penelitian kualitatif bahwa:

...penelitian yang bermaksud untuk memahami fenomena tentang apa yang dialami subjek penelitian misalnya perilaku, persepsi, motivasi, tindakan, dll., secara holistik, dan dengan cara deskripsi dalam bentuk kata-kata dan bahasa, pada suatu konteks khusus yang alamiah dan dengan memanfaatkan berbagai metode alamiah.

Dengan demikian semakin memperkuat bahwa penelitian ini sesuai dilakukan dengan pendekatan kualitatif untuk menggali lebih dalam makna yang tersirat dan tersurat sesuai dengan pertanyaan peneltian yang diajukan sehingga dapat terlihat jelas gambaran yang bermakna bagi pengembangan keilmuan dan juga tujuantujuan praktis lainnya.

Analisi data dalam penelitian ini dibentuk dengan mengacu pada diagram fishbone yang digambarkan oleh peneliti, sebagai berikut:

\section{Bagan 1 Diagram Fisbone Pendidikan Kewarganegaraan Berbasis Kompetensi Wawasan Global Warga Negara}

Penelitian Redi Yamanto (2014). Peranan Pendidikan Kewarganegaraan Dalam Membentuk Kesadaran Mahasiswa Sebagai Warga global

Penelitian Syifa Siti Aulia
(2014)Pengaruh Pembelajaran VCT
Analisis Nilai Dilema Moral Terhadap
Kompetensi Wawasan Global Warga
Negara

Feriyansyah (2014)Warga Negara Digital Sebagai Instrumen Menuju Warga Negara Global (Penelitian Grounded Theory Tentang Dampak Kemajuan Teknologi Informasi Dan Komunikasi Terhadan Praktik Kewaroaneoaraan)

Penelitian Mukhamad Murdiono (Murdiono, 2014)Pendidikan Kewarganegaraan Untuk Membangun Wawasan Global Warga Negara Muda
Pembelajaran Pendidikan Kewarganegaraan Berbasis Kompetensi Wawasan Global Warganegara Muda

Sumber: Data Diolah Penulis, 2015 


\section{HASIL DAN PEMBAHASAN}

\section{A. Proses pembelajaran mata kuliah Pendidikan Kewarganegaraan untuk membentuk wawasan global warga negara muda di Fakultas Keguruan dan}

\section{Ilmu Pendidikan Universitas Ahmad Dahlan}

Temuan penelitian yang diperoleh dilapangan menggambarkan proses pembelajaran mata kuliah Pendidikan Kewarganegaraan dengan kajian beberapa hal sebagai berikut:

\section{Perencanaan Pembelajaran}

Pembentukan wawasan global dimulai dari perencanaan pembelajaran yang dipersiapkan oleh dosen. Mahasiswa FKIP UAD merasakan bahwa dalam pelaksanaan pembelajaran perencanaan menjadi bagian yang telah dilakukan dalam pembentukan wawasan global warga negara terlihat dari penyampaian dosen yang baik, penyampaian materi yang disertai dengan contoh terkini, materi yang disajikan direncanakan sesuai dengan kebutuhan mahasiswa untuk berwawasan global. Diharapkan dengan perencanaan yang baik dari para dosen UAD ini dapat terjadi pembentukan warga negara yang cerdas (an informed citizenry), warga negara yang mampu berpikir analitis (ananlytical citizenry), dan warga negara yang memiliki komitmen dan mampu melibatkan diri (a committed and involved citizenry) (Wahab \& Sapriya, 2011, hal. 314).

Hasil observasi di lapangan di temukan bahwa dosen memiliki kelengkapan Rencana Pembelajaran Semester dalam mata kuliah Pendidikan Kewarganegaraan, dari sembilan Program Studi di FKIP dengan 12 dosen yang mengampu Mata Kuliah Pendidikan Kewarganegaraan didapatkan Rencana Pembelajaran yang disesuaikan dengan kebutuhan dan visi misi perguruan tinggi, didasarkan pada peraturan perundang-undangan yakni Undang-Undang No 12 tahun 2012 tentang Pendidikan Tinggi bahwa perguruan tinggi memiliki otonomi dalam penyusunan kurikulum, namun pada pelaksanaannya diperlukan rambu-rambu yang sama agar dapat mencapai hasil yang optimal. Rambu-rambu yang sama ini dalam pembentukan wawasan global warga negara terlihat dari visi Universitas Ahmad Dahlan Menjadi Perguruan Tinggi Muhammadiyah Berkelas Internasional Berlandaskan Nilai-nilai Keislaman yang kemudian selaras dengan Pada Tahun 2020 FKIP UAD menjadi Lembaga Pendidikan Tenaga Kependidikan (LPTK) 
Muhammadiyah yang unggul dan inovatif dalam pembelajaran berbasis riset dan teknologi dalam kehidupan akademik Islami.

Berdasarkan visi yang tergambarkan di atas, maka perencanaan pembelajaran dalam mata kuliah pendidikan kewarganegaraan dalam kurikulumnya dikembangkan untuk mewujudkan visi tersebut sehingga dalam perencanaan pembelajaran yang dibuat oleh dosen pendidikan kewarganegaraan terikat dengan pembentukan wawasan global warga negara karena disesuaikan dengan kalimat "Berkelas Internasional Berlandaskan Nilai-nilai Keislaman" yang terkait dengan kompetensi wawasan global warga negara.

\section{Metode Pembelajaran}

Berdasarkan temuan lapangan diperoleh bahwa metode pembelajaran yang digunakan dalam pembentukan kompetensi wawasan global warga negara, di FKIP UAD terdiri dari beberapa metode pembelajaran yakni:

a. Studi kasus

b. Cooperative learning

c. Problem solving

Namun, dari temuan di lapangan di peroleh bahwa beberapa mahasiswa menganggap penyampaian materi dengan ceramah dominan dilakukan oleh beberapa dosen yang membuat pembentukan kompetensi wawasan global warga negara melalui mata kuliah pendidikan kewarganegaraan tidak sampai pada tujuan utamanya. Hal ini sedikit bertolak belakang dengan pendapat Dijkstra (2004, hal. 17) bahwa instruction design is the communication between a student and a teacher (expert), and the rules for how to design and develop this communication. Hal ini berarti perlu adanya desain pembelajaran yang mampu memberikan mahasiswa gairah belajar dan hubungan antara mahasiswa dan dosen lebih komunikatif, serta materi yang dibelajarkan. Selain itu diperlukan persepsi minimal mendekati sama tentang pentingnya kompetensi wawasan global sehingga dengan minat yang ada membantu pemahaman kompetensi wawasan global mahasiswa sebagaimana hasil penelitian Alexander, Kulikowich, \& Jetton tahun 1994 bahwa ada hubungan positif antara kepentingan pribadi (minat-penulis) dengan pembelajaran dalam topik tersebut (Pellegrino, 2004). Oleh karena itu ketertarikan mahasiswa dengan materi sangat membantu proses pembelajaran di kelas. 
Pembentukan kompetensi wawasan global warga negara secara teoritis memang tidak hanya terkait dengan pengetahuan saja namun sampai pada keterampilan dan juga sikap warga negara yang berwawasan global, sehingga metode pembelajaran dalam pembentukan wawasan global warga negara tidak hanya terbentuk dengan proses transfer pengetahuan saja namun harus sampai pada pembentukan kompetensi keterampilan dan sikap yang berwawasan global.

\section{Media Pembelajaran}

Temuan penelitian yang diperoleh di lapangan mengungkap bahwa media pembelajaran yang digunakan lebih statis. Dominan aktifitas mahasiswa di dalam kelas lebih banyak dengan hanya melihat video ataupun powerpoint di dalam kelas. Namun demikian berdasarkan hasil penelitian Arpannudin, Abdulkarim, dan Bestari (2015, hal. 61) bahwa peran media pembelajaran sangat penting untuk meningkatkan pemahaman materi dan pembentukan sikap dalam pembelajaran Pendidikan Kewarganegaraan.

Temuan penelitian selajutnya bahwa kondisi hanya melihat video ataupun powerpoint di dalam kelas, sehingga jauh dari pembentukan keterampilan berwawasan global dimana mahasiswa seharusnya mengenali luasnya lingkungan dan permasalahan-permasalahan yang dihadapi masyarakat terutama berkaitan dengan pembentukan kompetensi wawasan global. Lebih lanjut Knowles, Dankenwald, Merian, Gross dan Jarvis dalam Sujana (2006, hal. 63) mengemukakan teori andragogi bahwa kunci keberhasilan dalam proses pembelajaran peserta didik terletak pada keterlibatan diri mereka dalam proses pembelajaran. Teori ini sejalan dengan tujuan media pembelajaran untuk memperlancar proses pembelajaran dan pada akhirnya diharapkan dapat mempertinggi hasil belajar.

Winataputra dalam Arpannudin (2014) menegaskan bahwa hal yang harus diperhatikan dalam menetapkan media yang dipakai dalam pembelajaran Pendidikan Kewarganegaraan adalah bahwa media itu harus dapat memberikan rangsangan kognitif atau cognitive simulation. Dengan terciptanya kondisi psikologi tersebut maka mahasiswa ditantang sekaligus diberikan kebebasan untuk mengekspresikan apa yang dia rasakan dan sikap yang akan dia tampilkan. Harapan pembelajaran Pendidikan Kewarganegaraan kedepan adalah yang paling sesuai 
dengan teori pengalaman Dale yang memberikan klasifikasi pengalaman dalam proses pembelajaran untuk mencapai tujuan pembelajaran dari konkret ke tingkatan yang paling abstrak (Sadiman, 1990).

B. Aktifitas mahasiswa dalam mata kuliah Pendidikan Kewarganegaraan untuk membentuk wawasan global warga negara muda di Fakultas Keguruan dan Ilmu Pendidikan Universitas Ahmad Dahlan

Berdasarkan hasil temuan penelitian dapat digambarkan bahwa komponenkomponen pembentukan wawasan global warga negara yang terdiri dari 3 komponen utama yakni:

1. Pengetahuan yang dibentuk berkaitan dengan wawasan global warga negara

2. Keterampilan yang dibentuk berkaitan dengan wawasan global warga negara

3. Sikap yang dibentuk berkaitan dengan wawasan global warga negara

Komponen-komponen tersebut di atas bersinggungan apabila dikaitkan dengan kompetensi warga negara global memiliki elemen kunci knowledge, skills, and attitudes untuk membekalinya hidup sebagai warga global (Adam \& Carfagna, 2006; Carlsson-Paige, 2005; Fisher, 1985; Osler, 2002 ; Pike, 1999; Gibson, Rimmington, \& Landwehr-Brown, 2008). Artinya warga negara global memiliki elemen kunci yaitu: pengetahuan, keterampilan dan sikap untuk hidup sebagai warga global. Konsep-konsep ini lebih bermakna apabila dibarengi dengan pengalaman interaksi pelajar dengan dunia luar yang berbeda sehingga akan lebih bermakna.

Ketiga komponen di atas dikembangkan didasarkan pada materi ajar dalam mata kuliah Pendidikan kewarganegaraan yang secara garis besar berdasarkan kurikulum perguruan tinggi Universitas Ahmad Dahlan tergambarkan sebagai berikut:

1. Pendidikan Kewarganegaraan di Perguruan Tinggi

2. Identitas Nasional Indonesia

3. Hak dan Kewajiban Warga Negara Indonesia

4. Demokrasi Indonesia

5. Konstitusi Indonesia

6. Hak Asasi Manusia

7. Wawasan Nusantara

8. Ketahanan Nasional

9. Integrasi Nasional 
Berdasarkan temuan penelitian tergambarkan 9 materi ajar yang dikembangkan dalam mata kuliah pendidikan kewarganegaraan di FKIP Universitas Ahmad Dahlan tersebut berkaitan dengan pengetahuan yang dibentuk, tergambarkan dalam tabel di bawah ini:

Tabel 1 Keterkaitan Aspek Pengetahuan dalam Wawasan Global Warga Negara dengan Materi Ajar Pendidikan Kewarganegaraan

\begin{tabular}{|c|c|}
\hline $\begin{array}{l}\text { Pengetahuan dalam Pembentukan } \\
\text { Wawasan Global Warga Negara }\end{array}$ & $\begin{array}{l}\text { Materi Ajar Dalam Mata Kuliah } \\
\text { Pendidikan Kewarganegaraan }\end{array}$ \\
\hline Pemahaman Budaya & $\begin{array}{ll}- & \text { Identitas Nasional } \\
\text { - } & \text { Wawasan Nusantara }\end{array}$ \\
\hline Keragaman & $\begin{array}{ll}\text { - } & \text { Hak dan Kewajiban } \\
\text { - } & \text { Wawasan Nusantara } \\
\text { - } & \text { Hak Asasi Manusia } \\
\text { - } & \text { Integrasi Nasional }\end{array}$ \\
\hline Globalisasi & $\begin{array}{ll}- & \text { Ketahanan Nasional } \\
\text { - } & \text { Integrasi Nasional }\end{array}$ \\
\hline Saling Ketergantungan & $\begin{array}{ll}\text { - } & \text { Hak dan Kewajiban Warga } \\
\text { Negara Indonesia } \\
\text { - } \quad \text { Hak Asasi Manusia } \\
\text { - } \quad \text { Ketahanan Nasional }\end{array}$ \\
\hline Penyimpangan Global & $\begin{array}{ll}\text { - } & \text { Identitas Nasional } \\
\text { - } & \text { Hak dan Kewajiban } \\
\text { - } & \text { Konstitusi Indonesia }\end{array}$ \\
\hline Perdamaian dan Konflik & $\begin{array}{ll}- & \text { Demokrasi } \\
\text { - } & \text { Integrasi Nasional } \\
\text { - } & \text { Hak dan Kewajiban }\end{array}$ \\
\hline Alam dan lingkungan & $\begin{array}{ll}- & \text { Hak dan Kewajiban } \\
\text { - } & \text { Konstitusi Indonesia }\end{array}$ \\
\hline Pembangunan Berkelanjutan & $\begin{array}{ll}\text { - } & \text { Demokrasi } \\
\text { - } & \text { Konstitusi } \\
\text { - } & \text { Wawasan Nusantara }\end{array}$ \\
\hline Kehidupan masa yang akan datang & $\begin{array}{ll}\text { - } & \text { Identitas Nasional } \\
\text { - } & \text { Demokrasi } \\
\text { - } & \text { Konstitusi Indonesia } \\
\end{array}$ \\
\hline Keadilan Sosial & $\begin{array}{ll}\text { - } & \text { Hak dan Kewajiban } \\
\text { - } & \text { Demokrasi Indonesia } \\
\text { - } & \text { Integrasi Nasional } \\
\end{array}$ \\
\hline
\end{tabular}

Dari hasil wawancara beberapa mahasiswa terungkap bahwa dalam pembentukan wawasan global warga negara untuk aspek pengetahuan teridentifikasi sebagai berikut: 


\section{Pemahaman Budaya}

Mata Kuliah Pendidikan kewarganegaraan memfasilitasi pembentukan wawasan global warga negara melalui komponen pemahaman budaya. Berdasarkan hasil temuan penelitian terungkap bahwa pemahaman budaya terbentuk melalui mata kuliah pendidikan kewarganegaraan dapat memperkuat wawasan global warga negara terutama berkaitan dengan pemaparan pentingnya penguatan budayabudaya lokal dan selain itu terbukanya pemahaman mahasiswa dengan kebudayaankebudayaan asing yang sesuai maupun tidak dengan jati diri bangsa Indonesia.

\section{Keragaman}

Mata Kuliah Pendidikan Kewarganegaraan memfasilitasi pembentukan wawasan global warga negara melalui pemahaman dengan keragaman bangsa Indonesia. Berdasarkan hasil temuan penelitian terungkap bahwa pemberian contoh negara Indonesia sebagai negara yan memiliki keragaman adat budaya, bahasa, dan agama menjadi kajian materi yang dibahas dalam perkuliahan, hal ini memperkuat pembentukan wawasan global warga negara walaupun masih sedikit kajian yan membahas tentang keragaman bangsa-bangsa di dunia.

\section{Globalisasi}

Berdasarkan temuan penelitian terungkap bahwa mahasiswa FKIP Universitas Ahmad Dahlan dalam proses perkuliahan Pendidikan Kewarganegaraan sering diingatkan dengan dampak globalisasi terutama bagi kehidupan warga negara, yang hakikatnya timbul sebagai konsekuensi dari berkembangnya teknologi informasi.

\section{Saling Ketergantungan}

Berdasarkan temuan penelitian dapat diuraikan bahwasanya dalam pembentukan wawasan global warga negara melalui mata kuliah pendidikan kewarganegaraan dititikberatkan pada pemahaman bahwa manusia sebagai makhluk sosial yang hakikatnya saling membutuhkan satu sama lain tidak hanya dalam komponen lokal namun juga sampai pada tatanan global.

\section{Penyimpangan Global}

Penyimpangan global dalam materi kuliah pendidikan kewarganegaraan terutama berkaitan dengan permasalahan-permasalahan yang terjadi dalam ranah dunia, yang dapat diselesaikan dengan membenahi wilayah lokal terlebih dahulu. 


\section{Perdamaian dan Konflik}

Berdasarkan temuan penelitian terungkap bahwa mahasiswa FKIP UAD memahami konsep perdamaian dan konflik melalui mata kuliah pendidikan kewarganegaraan sebagai sebuah tantangan yang harus dihadapi oleh semua lapisan masyarakat terutama dalam proses pembentukan wawasan global warga negara.

\section{Alam dan Lingkungan}

Alam dan lingkungan menjadi indikator yang penting dalam pembentukan wawasan global warga negara. Mata kuliah pendidikan kewarganegaraan senantiasa memfasilitasi pembahasan menenai alam dan linkungan yang tidak terapat batasan dalam pemanfaatannya artinya alam linkungan di bumi baian manapun saling berkesinambungan satu sama lain.

\section{Pembangunan Berkelanjutan}

Berdasarkan temuan penelitian bahwa pembentukan wawasan global warga negara melalui mata kuliah pendidikan kewarganegaraan menjadikan pembangunan berkelanjutan sebagai pembahasan dalam penguatan materi yang disampaikan karena dengan pembangunan berkelanjutan ini akan memperkuat setiap lapisan dalam kehidupan berbangsa dan bernegara.

\section{Rencana Masa depan}

Rencana masa depan dalam kajian materi-materi melalui mata kuliah pendidikan kewarganegaraan tersampaikan dengan melihat permasalahanpermasalahan terkini atau isu-isu masyarakat terkini yang selanjutnya menjadi rancangan pembentukan warga negara yang baik yang dikehendaki di masa yang akan datang sesuai denan kopetensi yang harus dimiliki warga negara di abad 21 nanti.

\section{Keadilan Sosial}

Komponen keadilan sosial dalam pembentukan wawasan global warga negara melalui mata kuliah pendidikan kewarganegaraan menghendaki sila kelima pancasila sebagai penopang implementasi keadilan sosial bagi seluruh komponen warga negara.

Selain sepuluh aspek yang dikemukakan di atas, berdasarkan temuan penelitian dalam pembentukan wawasan global mahasiswa FKIP Universitas Ahmad Dahlan ditemukan bentuk-bentuk keterampilan yang menjadi kompetensi 
yang dibentuk dalam wawasan global warga negara. Keterampilan-keterampilan tersebut teridentifikasi sebagaimana di bawah ini:

1. Keterampilan berpikir kritis dengan mengkaji berbagai current issue yang terjadi di kehidupan masyarakat

2. Keterampilan berkomunikasi dengan diskusi dalam proses pembelajaran

3. Keterampilan bekerja sama dan resolusi konflik, keterampilan ini dilakukan dengan proses pembelajaran studi kasus yang banyak disampaikan oleh dosen.

Berdasarkan temuan penelitian, aspek-aspek sikap di bawah dapat dikembangkan melalui mata kuliah pendidikan kewarganegaraan dalam pembentukan wawasan global warga negara:

1. Saling Menghormati

2. Empati terhadap budaya lain

3. Menghargai keberagaman

4. Menjunjung tinggi keadilan

5. Menjunjung tinggi komitmen

6. Kepedulian terhadap lingkungan

Temuan-temuan penelitian di atas selaras dengan pandangan Noddings (Rapoport, 2008, p. 92) bahwa global citizen adalah seseorang yang dapat hidup dan bekerja efektif di manapun berada. Oleh karena itu mata kuliah Pendidikan Kewarganegaraan didesain untuk mempersiapkan warga negara muda mampu untuk berinteraksi dengan lingkunga di luar dirinya sebagaimana Oxfam melihat global citizen sebagai seseorang yang 'aware of the wider world and has a sense of their own role as a world citizen; respects and values diversity; willing to act to make the world a more equitable and sustainable place; take responsibility for their actions. (Education Above All, 2012)

Selaras dengan di atas, McIntosh (Rapoport, 2008) menyebutkan global citizen harus memiliki kebiasaan berpikir, hati, tubuh dan jiwa yang mampu untuk bekerja dan mempersiapkan hubungan dan koneksi melintasi perbedaan dan keunikannya, sekaligus menjaga dan memperdalam rasa identitas dan integritas sendiri.

Pendapat lain mengenai kompetensi untuk hidup secara global yang harus dimiliki oleh warga negara dikemukakan oleh Zhao (Wolbring, 2012) bahwa 
sebagai warga dunia mereka harus menyadari akan suasana isu-isu global, peduli dengan orang yang jauh dari dirinya, memahami integrasi ekonomi global, mengapresiasi interkoneksi dan interdependensi, peduli dan melindungi keragaman budaya, memperjuangkan keadilan untuk semua dan melindungi bumi untuk semua manusia.

\section{Hambatan dalam mata kuliah Pendidikan Kewarganegaraan untuk membentuk wawasan global warga negara muda di Fakultas Keguruan dan Ilmu Pendidikan Universitas Ahmad Dahlan}

Setelah dilakukan berbagai analisis mengenai kompetensi yang dibentuk dalam wawasan global warga negara melalui mata kuliah pendidikan kewarganegaraan di FKIP UAD maka teridentifikasi fakta lapangan bahwa ternyata masih banyak hambatan dalam proses pembelajaran dengan tujuan pembentukan wawasan global warga negara, antara lain sebagai berikut:

1. Kecenderungan sikap apatis dan tidak ingin menganalisis atau mencari solusi terhadap permasalahan global apa yang dihadapi oleh semua lapisan warga negara hal ini di perkuat dengan proses pembelajaran yang statis.

2. Ketidak mampuan berpikir kritis untuk mengkaji dan memberikan alternatif solusi dalam berbagai pemecahan masalah global

3. Tema-tema pembelajaran yang tidak menarik bagi young citizen untuk dipelajari, diamati, atau dianalisis.

Pemahaman bahwa masalah global itu hanya dipersempit dengan istilah globalisasi padahal materi dan banyak sekali isu yang dapat diangkat untuk proses pembentukan wawasan global warga negara melalui mata kuliah pendidikan kewarganegaraan. Lebih jauh dari sekadar istilah semata, globalisasi merupakan proses yang terus bergerak memasuki ranah-ranah yang tak pernah terbayangkan sebelumnya sehingga mobilisasi begitu cepat dan masif. Konsekuensinya adalah warga negara muda tidak bisa mengisolasi diri dari globalisasi dan harus memiliki wawasan global. Dengan demikian diperlukan warga negara berwawasan global (global citizen).

Konsep wawasan global warga negara (global citizenship) bukan merujuk pada status kewarganegaraan yang dimiliki oleh setiap warga negara. Bukan pada perubahan kewarganegaraan menjadi konteks global, namun lebih pada peran serta 
warga negara dalam konteks global. Penekanannya ada pada eksistensi warga negara dalam konteks kehidupan global (Rapoport, 2008).

Menanggapi tantangan global di atas, maka dalam proses implementasinya Pendidikan Kewarganegaraan di salah satu lingkungan pendidikan yakni di perguruan tinggi hendaknya berorientasi pada pembentukan wawasan global untuk warga negara sebagai proses pembentukan warga negara yang baik seperti yang diharapkan Noddings di atas. Cheng mengatakan bahwa kurikulum dan pembelajaran yang perlu dikembangkan untuk abad ke 21 ini seyogianya mengembangkan visi "globalization, localization, and individualization for multiple intelligence" (Winataputra \& Budimansyah, 2007).

\section{KESIMPULAN}

1. Proses pembelajaran mata kuliah Pendidikan Kewarganegaraan untuk membentuk wawasan global warga negara muda:

a. kurikulumnya dikembangkan untuk mewujudkan visi tersebut sehingga dalam perencanaan pembelajaran yang dibuat oleh dosen Pendidikan Kewarganegaraan terikat dengan pembentukan wawasan global warga negara karena disesuaikan dengan kalimat "Berkelas Internasional Berlandaskan Nilai-nilai Keislaman" yang terkait dengan kompetensi wawasan global warga negara.

b. Penyampaian materi dengan ceramah dominan dilakukan oleh dosen yang membuat pembentukan kompetensi wawasan global warga negara melalui mata kuliah pendidikan kewarganegaraan tidak sampai pada tujuan utamanya.

c. Media yang digunakan masih menggunakan media powerpoint yang kurang inovatif bagi mahsiswa.

2. Aktifitas mahasiswa dalam mata kuliah Pendidikan Kewarganegaraan untuk membentuk wawasan global warga negara muda menujukan mahasiswa telah aktif di dalam perkuliahan di dalam kelas.

3. Hambatan dalam mata kuliah Pendidikan Kewarganegaraan untuk membentuk wawasan global warga negara muda adalah pemahaman bahwa masalah global itu hanya dipersempit dengan istilah globalisasi padahal materi dan banyak 
sekali isu yang dapat diangkat untuk proses pembentukan wawasan global warga negara melalui mata kuliah pendidikan kewarganegaraan.

\section{UCAPAN TERIMA KASIH}

Terima kasih yang sebesar-besarnya kepada Lembaga Penelitian dan Pengembangan Universitas Ahmad Dahlan yang telah memberikan kepercayaan kepada penulis untuk melakukan penelitian.

\section{DAFTAR PUSTAKA}

Adam, J., \& Carfagna, A. (2006). Coming of Age in A Globalized World: The Next Generation. Bloomsfield, CT: Kumarian Press.

Arpannudin, I. (2014). Pengaruh Penggunaan Media Video Dengan Pendekatan Saintifik Dalam Pembelajaran Pendidikan Kewarganegaraan Terhadap Sikap Antikorupsi Siswa. Bandung: Sekolah Pascasarjana Universitas Pendidikan Indonesia. Tesis. Tidak Diterbitkan.

Arpannudin, I., Abdulkarim, A., \& Bestari, P. (2015). Pengaruh Media Video dengan Pendekatan Saintifik Dalam Pembelajaran Pkn Terhadap Sikap Antikorupsi SiswaDi Sman 8 Bandung. CIVICUS, 57-72.

Carlsson-Paige, N. \&. (2005). A Changing Vision of Education. Dalam Noddings, Educating Citizens for Global Awareness (hal. 107-121). New York: Teachers Colleges Press.

Dijkstra, S. (2004). Theoretical Foundations Of Learning And Instruction And Innovations Of Instructional Design And Technology. Dalam N. M. Dijkstra (Penyunt.), Curriculum, Plans, and Processes in Instructional Design: International Perspective (1 ed.). Mahwah, New Jersey: Lawrence Erlbaum Associates, Inc.

Education Above All. (2012). Education for Global Citizenship. Doha Qatar.

Fisher, S. \&. (1985). World studies 8-/3: A teacher's handbook. . London: Oliver and Boyd.

Gibson, L. K., Rimmington, G. M., \& Landwehr-Brown, M. (2008, Jan - Mar). Developing Global Awareness and Responsible World Citizenship With Global Learning. Roeper Review, 11-23.

Mertens, D. M. (2010). Research and Evaluation in Education and Psychology: Integrating Diversity with Quantitative,Qualitative, and Mixed Methods .3rd ed. London; California; New Delhi; Singapore: SAGE Publication. Inc. 
Moleong, L. (2010). Metodologi Penelitian Kualitatif. Bandung: PT. Remaja Rosdakarya.

Osler, A. \&. (2002 ). Globalisation and cosmopolitan citizenship: Educational responses. Staffordshire England: Cromwell Press.

Pellegrino, J. W. (2004). Complex Learning Environments: Connecting Learning Theory, Instructional Design, and Technology. Dalam N. M. Dijkstra (Penyunt.), Curriculum, Plans, and Processes in Instructional Design: International Perspective ( (1 ed.). Mahwah, New Jersey: Lawrence Erlbaum Associates, Inc.

Pike, G. \&. (1999). In the global classroom: Book I. Toronto:: Pippin.

Rapoport, A. (2008). A Forgotten Concept: Global Citizenship Education and State Social Studies Standards. The Journal of Social Studies Research, 33(I), 91112.

Sadiman, A. (1990). Media Pendidikan, Pengertian Pengembangan dan Pemanfaatan. Jakarta: Rajawali.

Sujana, N. (2006). Penilaian Hasil Proses Belajar Mengajar. Bandung: PT. Remaja Rosdakarya.

Wahab, A. A., \& Sapriya. (2011). Teori dan Landasan Pendidikan Kewarganegaraan. Bandung: Alfabeta.

Winataputra, U. S., \& Budimansyah, D. (2007). Civic Education Konteks, Ladasan, Bahan Ajar dan Kultur Kelas. Bandung: Program Studi Pendidikan Kewarganegaraan Sekolah Pascasarjana UPI.

Wolbring, G. (2012). Citizenship Education Through an Ability Expectation and "Ableism" Lens: The Challenge of Science and Technology and Disabled People. Education Sciences, 2(3), 150-164. 